Scientific Journal. ISSN 2595-9433

Volume 2, Number 2, Article n. 6, July/December

D.O.I. http://dx.doi.org/10.35418/2526-4117/v2n2a6

Received: 04/08/2019 - Accepted: 06/25/2019

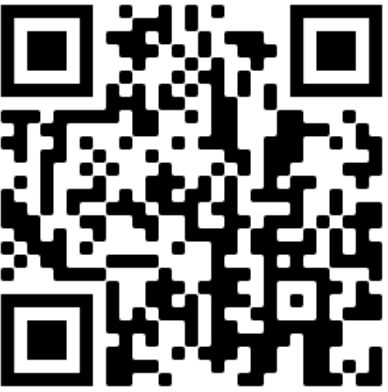

\title{
POTENTIAL OF POPCORN S 4 LINES FOR RESISTANCE TO SOUTHERN CORN LEAF BLIGHT
}

(D) Júlio Cesar Gradice Saluci ${ }^{1}$, (D) Marcelo Vivas ${ }^{1 *}$, (D) Rafael Nunes de Almeida $^{1}$, (D) Iris Petronilia Dutra ${ }^{1}$, (D) Mayara Cazadini Carlos ${ }^{1}$, (iD Antonio Teixeira do Amaral Júnior ${ }^{2}$, (D) Carlos Alberto Scapim ${ }^{3}$

1 Laboratório de Engenharia Agrícola, Universidade Estadual do Norte Fluminense Darcy Ribeiro (UENF), Campos dos Goytacazes, RJ;

2 Laboratório de Melhoramento Genético Vegetal, Universidade Estadual do Norte Fluminense Darcy Ribeiro (UENF), Campos dos Goytacazes, RJ;

3 Departamento de Agronomia, Universidade Estadual de Maringá (UEM), Maringá, PR.

*Corresponding autor: Marcelo Vivas (mrclvivas@hotmail.com).

Abstract: Popcorn crop is distinguished by its higher profitability when compared to the common maize. Nevertheless, it has a scarce amount of information and a genetic material resistant to foliar diseases that affect the crop. In view of the mentioned conditions, this work aimed at evaluating popcorn $\mathrm{S}_{4}$ lines, coming from different genealogies, for resistance to $B$. maydis. The experiment was conducted at a greenhouse in augmented block designs, with four blocks, and 78 lines from 13 genealogies were evaluated. The L55, L-70, L-77, L-88, P-01, and P-08 lines were considered as controls and repeated in all blocks. The incidence of B. maydis in the plant was evaluated at 7 days, and the severity in the leaf, at 7 and 14 days after inoculation. The data of lines were subjected to analysis of variance; and the means were discriminated by the t-student test, considering as resistant the lines whose means did not differ from zero. With the purpose of evaluating the merits of the populations originated from the lines, the $\mathrm{S}_{4}$ lines were grouped, following each genealogy, using boxplot graphs. Regarding the leaf severity, there was a significant effect for both evaluations, proving there was variability among the different lines. In the first evaluation, 83.3 percent of the lines reported means statistically equal to zero; after 14 days, the percentage decreased to 37.2 percent. In the second evaluation of severity, lines resistant to B. maydis obtained from SE_013, SAM, PR_023, PARA_172, PA_170_R, PA_091, CHZM_13_134, BOZM_260, ARZM_07_049 could be identified.

Keywords: plant breeding, genetic resistance, Bipolaris maydis. 


\section{Introduction}

Of all the so-called "special maize", the popcorn stands out for its great profitability, being responsible for its impact on different economic areas related to agribusiness, apart from being a high-quality nutritional and functional food, exclusively aimed at human consumption (Freitas et al., 2013; Paraginski et al., 2016).

Even though Brazil is the second largest producer of popcorn, its production does not attend the domestic consumer market, being, hence, one of the crops with a high growth perspective in the country. Even being a promising market, the popcorn crop has been the target of very few studies aimed at optimizing its yield. To achieve this goal, alternatives such as developing more productive cultivars, able to generate a final product of better quality (Silva et al., 2013; Vittorazzi et al., 2013; Vieira et al., 2017; Guimarães et al., 2018), have been pursued. One of the challenges to reach these aims is to obtain genotypes more adapted to biotic and abiotic stresses which directly affect the productivity of culture (Kurosawa et al., 2017; Santos et al., 2017a; Santos et al., 2017b; Schwantes et al., 2017; Gabriel et al., 2018; Coan et al., 2018).

Special attention should be given to foliar diseases, such as the Cercosporazeae-maydis Tehon and Daniels, Puccinia polysora Underw, Physopellazeae (Mains) Cummins \& Ramachar, Exserohilum turcicum (Pass.) K. J. Leonard and E. G. Suggs, and Bipolaris maydis (Nisik. and Miyake) Shoemaker (Casela et al., 2006; Sabato et al., 2013; Santos et al., 2017b). These diseases attack plants damaging foliar tissues and reducing the photosynthetic area, interfering in characters related to crop yield and grain quality (Nihei and Ferreira, 2012). The Southern corn leaf blight, caused by B. maydis, has raised concerns about maize farming, mostly in popcorn, because of the high severity of the disease in crops with susceptible genotypes (Huang et al., 2010; Altaf et al., 2016).

The plant breeding program is a relevant control strategy for the incidence of B. maydis in maize, allowing evaluation, selection, and recombination of genotypes resistant to the pathogen (Mubeen et al., 2017). As a general issue, the breeding programs for the crop present two aspects: the obtaining of breeding populations and the obtaining of hybrids. In both cases, genetic material higher than the ascendants is searched (Paterniani and Miranda Filho, 1978; Arnhold, 2008). In this regard, studies that aim at evaluating and characterizing genotypes are significant for the understanding genetic variability in germplasm banks, mainly when they refer to resistance to foliar diseases for the popcorn crop (Kurosawa et al., 2017). One limiting factor behind such evaluation is that the acquisition and evaluation of inbred lines, to obtain hybrids in a crop, is a slow process that demands great financial investment (Marcondes et al., 2015).

On this point, the evaluation and empirical selection of partially inbred lines is a viable alternative to reduce the number of families throughout the study, saving resources. Another way is the use of designs that make it possible to efficiently evaluate a number of genetic materials, even with restriction of resources and/or genetic material (Peternelli et al., 2009; Ribeiro et al., 2016). The augmented block design allows evaluating the treatments with only one replication in the experiment, enabling the evaluation of a large number of treatments; consequently, it is of great importance for the plant breeding programs. At first, it was developed for the sugarcane breeding, but it has been used successfully in other crops (Federer, 1956; Peternelli et al., 2009; Arnhold et al., 2010).

Therefore, this study aimed at evaluating the potential of popcorn $\mathrm{S}_{4}$ lines from different genealogies concerning resistant to southern corn leaf blight.

\section{Material and methods}

This research was carried out at the Universidade Estadual do Norte Fluminense Darcy Ribeiro, in Campos dos Goytacazes City, Rio de Janeiro State, Brazil. The trial was conducted in a greenhouse in the augmented block design of Federer (Federer, 1956), with four replications and six controls. The design was selected by restrictions as to the number of seeds available for planting. Eighty-four popcorn lines were evaluated, 6 lines - L-55, L-70, L-77, L-88, P-01, P-08 - considered controls, repeated in all blocks, and 78 lines in $\mathrm{S}_{4}$, based on single randomized plots along the blocks (Table 1). 
Table 1. Description of the origin of the open-pollinated population and of the number of popcorn $\mathrm{S}_{4}$ lines from each population.

\begin{tabular}{lcl}
\hline $\begin{array}{l}\text { Name of the } \\
\text { population }\end{array}$ & $\begin{array}{c}\text { Number of } \\
\text { evaluated lines }\end{array}$ & Origin of the population \\
\hline ARZM 05 083 & 3 & Centro Internacional para el Mejoramiento de Maíz y Trigo - Argentina \\
\hline ARZM 07 049 & 6 & Centro Internacional para el Mejoramiento de Maíz y Trigo - Argentina \\
\hline ARZM 13 050 & 7 & Centro Internacional para el Mejoramiento de Maíz y Trigo - Argentina \\
\hline BOYA 462 & 2 & Centro Internacional para el Mejoramiento de Maíz y Trigo - Colombia \\
\hline BOZM 260 & 13 & Centro Internacional para el Mejoramiento de Maíz y Trigo - Bolivia \\
\hline CHZM 13 134 & 2 & Centro Internacional para el Mejoramiento de Maíz y Trigo - Chile \\
\hline PA 091 & 8 & Universidade Estadual de Maringá - Brazil \\
\hline PA 170 R & 4 & Centro Internacional para el Mejoramiento de Maíz y Trigo - Paraguay \\
\hline PARA-172 & 6 & Centro Internacional para el Mejoramiento de Maíz y Trigo - Paraguay \\
\hline PR-023 & 7 & Universidade Estadual de Maringá - Brazil \\
\hline SAM & 9 & North American landrace (USA) - South American variety \\
\hline SE-013 & 9 & Universidade Estadual de Maringá - Brazil \\
\hline URUG-298 & 2 & Centro Internacional para el Mejoramiento de Maíz y Trigo - Uruguay \\
\hline Total & 78 & \\
\hline
\end{tabular}

During the study, 5-liter plastic pots filled with substrate - soil:sand:cattle manure in a ratio of $2: 1: 1$ - were placed within the greenhouse. Four seeds were planted in every pot and, after the emergence of seedlings, a thinning was carried out, removing less vigorous plants, until two plants per pot were obtained, composing then one experimental unit.

The introduction of the pathogen was via inoculation with three isolates of $B$. maydis fungus, when plants reached the V4 phenological stage (presenting four expanded leaves, with collar, ligule, and visible auricles), in accordance with Santos et al. (2016). The inoculum applied consisted of a solution of conidia in a concentration of $2 \times 10^{4}$ conidium. $\mathrm{mL}^{-1}$, adjusted with a hemocytometer, with the addition of polyoxyethylene-sorbitan monolau-rate (Tween 20, Sigma Chemical Co) in the proportion of 1 drop $\mathrm{L}^{-1}$, to guarantee better coverage and humidification of the leaves by the inoculum suspension. The inoculation was by spraying the suspension on the plant up to the point of draining.

Seven days after inoculation, the incidence of leaves with Southern corn leaf blight was quantified by the ratio between the number of leaves with disease symptoms and the number of total leaves of the plant. Seven and fourteen days after inoculation, the severity of Southern corn leaf blight in leaf was determined, visually estimated with diagrammatic scale aid (James, 1971).
The incidence and severity data were submitted to analysis of variance by the $\mathrm{F}$ test using the Genes software (Cruz, 2013). The adjusted phenotypic values of severity of the $\mathrm{S}_{4}$ were evaluated by the t-student test, for comparative purposes, estimating the critical value of $\mathrm{t}$, from which the line means differ from zero. The adjusted phenotypic data of the $\mathrm{S}_{4}$ lines were used to infer the potential of the families; for such, boxplot graphs were built (Bussab and Morettin, 2017) applying R CORE TEAM (2016) statistical software.

\section{Results and discussion}

It was made possible, by analysis of variance, to evidence a significant difference between the lines for severity at 7 days, and for severity at 14 days, demonstrating the variability existing between the different genetic materials evaluated, with regard to resistance to Southern corn leaf blight. Meanwhile, for the incidence of B. maydis, no significance was found in the difference between the lines (Table 2). The variability observed between the lines in both severity evaluations points to the possibility of gains with the selection for this characteristic, allowing the selection of lines with a high level of resistance to Southern corn leaf blight.

The non-significant result for the variable incidence implied in the omission of the genetic parameters calculation. The non-significance for incidence requires equal levels of disease 
distribution in the leaf; hence, it must be inferred that the inoculation practiced was efficient in causing symptoms in the entire plant. In this respect, what will distinguish the genotypes will be the area affected by the pathogen, that is, the severity. For these variables, values of 63.14 and 74.89 were obtained for the coefficient of genetic variation, and values of 1.13 and 2.58 for the coefficient of relative variation, correspondingly, for severity at 7 and 14 days (Table 2). The values of more than 1 for the relative coefficient of variation $(\mathrm{CVr})$ reflect the possibility of reaching gains with genetic breeding (Vencovsky, 1987), suggesting high genetic variability in the genotypes evaluated.

Table 2. Summary of analysis of variance and estimates of genetic parameters for incidence and severity of Southern corn leaf blight (Bipolaris maydis), in tests of popcorn $\mathrm{S}_{4}$ lines in an augmented block design.

\begin{tabular}{|c|c|c|c|c|}
\hline \multirow{2}{*}{ Source of Variation } & \multirow{2}{*}{$\begin{array}{l}\text { Degree of } \\
\text { Freedom }\end{array}$} & \multicolumn{3}{|c|}{ Mean Square } \\
\hline & & Incidence & Severityat 7 days & Severityat 14 days \\
\hline Blocks & 3 & 1056774.00 & 0.23 & 0.65 \\
\hline Treatments (Adjusted) & 83 & $128.24^{\mathrm{ns}}$ & $0.15^{*}$ & $1.36 * *$ \\
\hline Controls (C) & 5 & $593.26^{* *}$ & $0.25^{* *}$ & $4.22 * *$ \\
\hline Lines (L) & 77 & $94.00^{\mathrm{ns}}$ & $0.14^{*}$ & $1.18 * *$ \\
\hline C. vs L. & 1 & $439.73^{\mathrm{ns}}$ & $0.06^{\mathrm{ns}}$ & $0.92 *$ \\
\hline Error & 15 & 1614382.00 & 0.07 & 0.16 \\
\hline Overall Mean & & 38.25 & 0.48 & 1.41 \\
\hline ControlMean & & 41.97 & 0.52 & 1.58 \\
\hline LineMean & & 37.10 & 0.46 & 1.36 \\
\hline CVe & & 33.21 & 54.32 & 28.06 \\
\hline CVg & & -- & 63.14 & 74.89 \\
\hline CVr & & -- & 1.13 & 2.58 \\
\hline
\end{tabular}

ns, * and **, respectively, non-significant at $5 \%$, significant at $5 \%$ and significant at $1 \%$ by the $\mathrm{F}$ test; $\mathrm{CVe}=$ Coefficient of experimental variation; $\mathrm{CVg}=$ Coefficient of genetic variation; $\mathrm{CVr}=\mathrm{Coefficient}$ of relative variation

In the first evaluation, severity after 7 days, it was noted, by means of the discrimination of the lines, that $83.3 \%$ of them reported means statistically equal to zero. Only $16.7 \%$ had means other than zero, being URUG-298-2, URUG-298-1, SE-013-5, PR023-4, PR-023-3, PARA-172-6, PARA-172-2, BOZM-260-8, BOZM-260-2, BOZM-260-1, ARZM-13-050-5, ARZM-07-049-3, and ARZM-05-083-3, considered as susceptible to the pathogen (Fig.1. A). With regard to the genealogies of the popcorn $\mathrm{S}_{4}$ line, only SAM, PA-170-R, PA-91, CHZM-13-134, and BOYA462 showed all the resistant lines, with means equal to zero, by test $t$.

As a result of the second severity evaluation, an increase in the disease severity was identified in the majority of the lines, resulting in a higher percentage of susceptible lines. From the 78 lines, 37.2\% displayed means equal to zero, and $62.8 \%$ were considered to be susceptible to B. maydis. Given the result of the second severity evaluation, resistance potential could be identified in the following lines: SE013-1, SE-013-2, SE-013-5, SE-013-6, SE-0137, SE-013-8, SE-013-9, SAM-4, SAM-6, SAM7, PR-023-3, PR-023-5, PR-023-6, PARA-1721, PARA-172-3, PARA-172-4, PA-170-R-1, PA170-R-2, PA-091-1, PA-091-2, PA-091-4, PA091-5, PA-091-6, PA-091-7, CHZM-13-134-2, BOZM-260-5, BOZM-260-9, BOZM-260-10, and ARZM-07-049-4. The potential for resistance to $B$. maydis, reported in genotypes from the PARA-172, BOZM-260, and ARZM07-049 breeds, was also confirmed by Kurosawa et al. (2017); nevertheless, the authors state a lack of information referring to the resistance to diseases in the popcorn genotypes in the Brazilian germplasm study.

With regard to the 13 genealogies from which the evaluated $\mathrm{S}_{4}$ lines were obtained, it could be noticed that there is variability within the families for Southern corn leaf blight incidence (Fig.2. A). 


\section{A)}

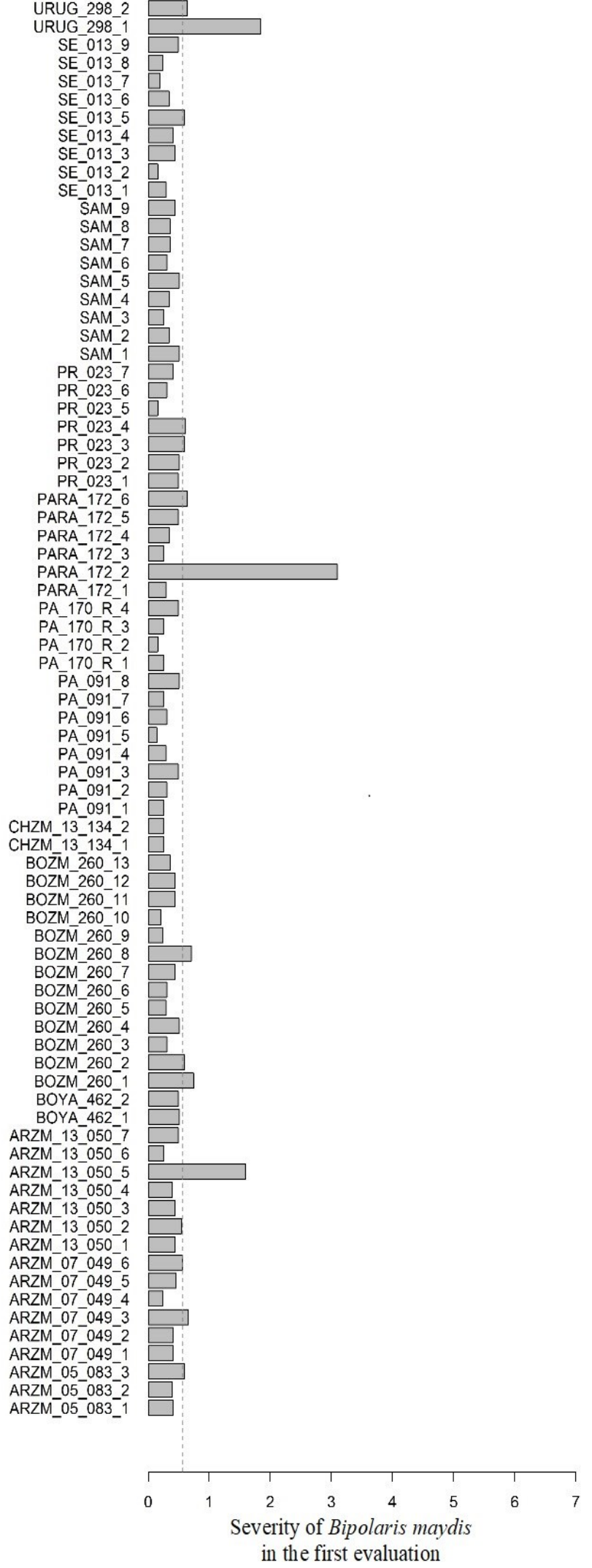

B)

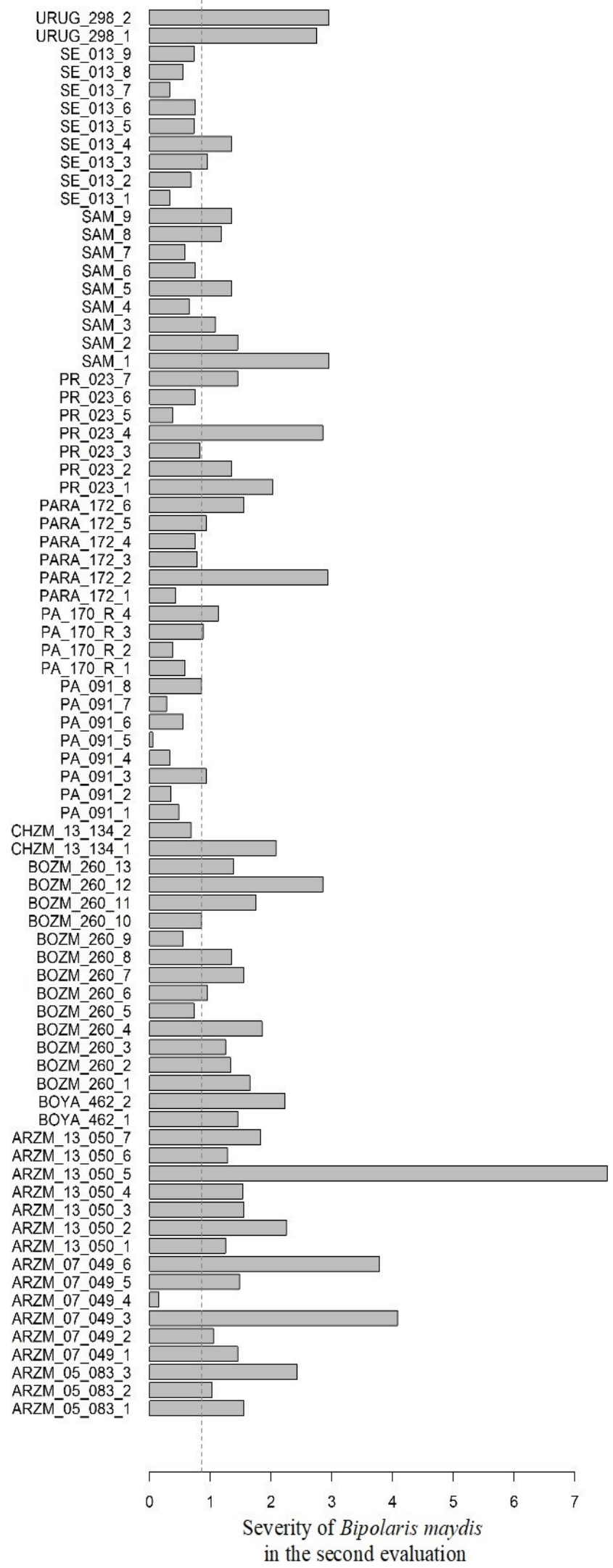

Figure 1. Popcorn $\mathrm{S}_{4}$ lines means evaluated in the augmented block design: A) Severity of Bipolaris maydis in the first evaluation, and B) Severity of Bipolaris maydis in the second evaluation. Lines that display bars with magnitudes lower than the line have a mean statically equal to zero. 

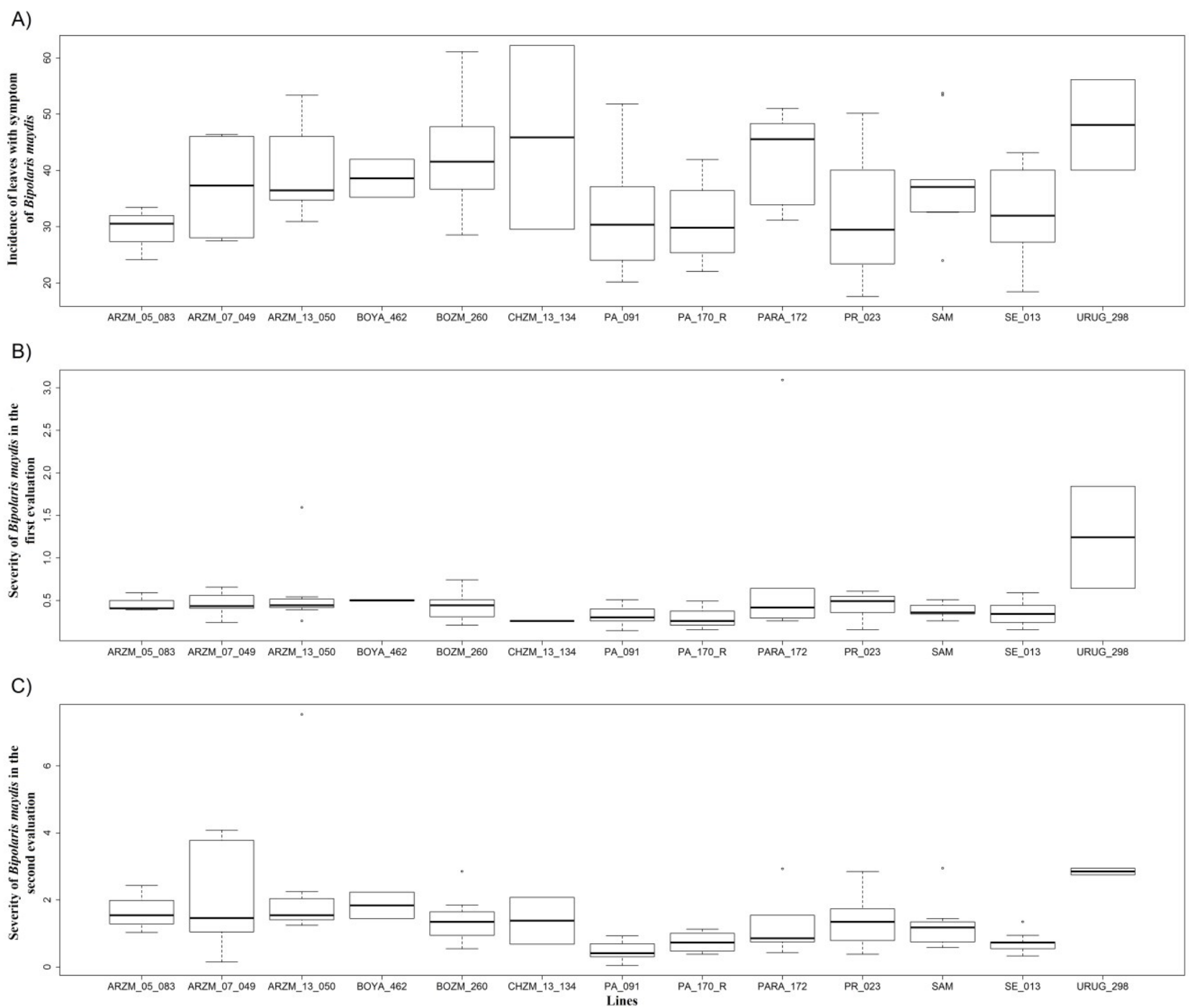

Figure 2. Distribution of popcorn lines as regards resistance to Southern corn leaf blight, grouped according to the families of origin, for Bipolaris maydis incidence (A), Bipolaris maydis severity at 7 days (B) and severity at 14 days $(\mathrm{C})$.

There was a high incidence of leaves showing symptoms of the disease, with the ARZM-05-083 population being the only one that presented the distribution of lines with less incidence: all below $35 \%$. In the other genealogies, there was a greater variability in the distribution of lines as regards incidence.

The occurrence of variability itself does not reflect negatively on the potential of the families for resistance to Southern corn leaf blight. It does evidence the need to obtain lines and evaluate them, when working with these families in breeding programs, in order to select those with the best performance concerning biotic stress of interest in the study.

For instance, in PA-091, PA-170-R, PR23 , and SE-013, the results indicated that it is possible to obtain lines with Southern corn leaf blight incidence below $20 \%$, a value even lower when compared with more resistant lines originating from ARZM-05-083.

Taking into account the severity of $B$. maydis in the leaf, considered in the first evaluation, the formation of three clusters was observed with respect to the distribution of lines by genealogy: URUG-298, SE-013, BOYA-462, and CHZM-12-134 presented a symmetrical distribution tendency; ARZM-05-083, ARZM07-049, ARZM-13-050, PA-091, PA-170-R, PARA-172, and SAM with right asymmetry; and a third group, formed by BOZM-260 and PR023, showed an asymmetry to the left (Fig.2. B). There was a smaller number of genotypes with left asymmetry. Meanwhile, this result indicates that the mean of these genotypes (genealogy) is 
below the median, so existing, great potential for resistance in these families.

During the second evaluation, at 14 days, a symmetrical distribution tendency could be noticed in ARZM-05-083, BOYA-462, BOZM260, CHZM-13-134, PA-170-R, and URUG-298. Asymmetry to the right was found in ARZM-07049, ARZM-13-050, PA-091, and PARA-172, and asymmetry to the left, in PR-023; SAM, and SE-013 (Fig.2., C). A larger number of families with a tendency to symmetrical distribution were noted. Even in $\mathrm{S}_{4}$, the possibility of exploring the line potential is made clear in popcorn breeding programs. Being this culture, in general, more susceptible to pests and maize diseases, lacking, thus, improved varieties in the area of resistance to foliar diseases (Arnhold, 2008), the present work becomes even more relevant. Therefore, the acquisition of inbred lines from the previously related accesses, with resistance potential, and their use will be worth a lot in the development of new cultivars of popcorn for the Brazilian agribusiness.

\section{Conclusions}

From all the lines evaluated herein, sources of resistance to Southern corn leaf blight caused by Bipolaris maydis were detected. Lines coming from the families SE 013, SAM, PR 023, PARA_172, PA_170_R, PA_091, CHZM_13 134, BOZM_260, and ARZM̄ 07 049 showe potential to be explored in popcorn breeding programs aiming at obtaining resistance to the Bipolaris maydis.

\section{References}

Altaf, M.;Raziq, F.; Khan, I.; Hussain, H.;Shah, B.;Ullah, W.;Naeem, A.; Adnan, M.;Junaid, K.;Shah, S.R.A.; AttaullahMazhar, I. 2016. Study on the response of different maize cultivars to various inoculum levels of Bipolaris maydis (Y. Nisik \& C. Miyake) shoemaker under field conditions. Journal of Entomology and Zoology Studies, 4: 533-537.

Arnhold, E.; Silva, R.G.; Viana, J.M.S. 2010. Selection of popcorn $\mathrm{S}_{5}$ inbred lines based on performance and genetic divergence. Acta Scientiarum Agronomy, 32: 279-283. http://dx.doi.org/-10.4025/actasciagron.v32i2.3886

Arnhold, E. 2008. Seleção para resistência a doenças foliares em famílias $\mathrm{S}_{1}$ de milho pipoca. Revista Ceres, 55: 89-93.

Bussab, W.O. and Morettin, P.A. 2017. Estatística Básica, 9 ed. Saraiva, São Paulo, 576p.

Huang, C.J.; Yang, K.H.; Liu, Y.H.;Lin, Y.J.; Chen, C.Y. 2010. Suppression of southern corn leaf blight by a plant growth-promoting rhizobacterium Bacillus cereus C1L. Annals Applied Biology, 157: 45-53. https://doi.org/10.1111/j.1744-7348.2010.00408.x

Casela, C.R.; Ferreira, A.S.da; Pinto, N. F. 2006. Doenças na Cultura do Milho. Empresa Brasileira de Pesquisa Agropecuária. Embrapa Agropecuária. Circular Técnica, 1 ed. 14p.

Coan, M.M.D.; Senhorinho, H.J.C.; Pinto, R.J.B.; Scapim, C.A.; Tessmann, D.J.; Williams, W.P.; Warburton, M.L.2018. Genome-wide association study of resistance to ear rot by in a tropical field maize and popcorn core collection. Crop Science, 58: 1-15. http://dx.doi.org/10.2135/cropsci2017-.05.0322

Cruz, C.D. 2013. GENES - a software package for analysis in experimental statistics and quantitative genetics. Acta Scientiarum Agronomy, 35: 271-276. http://dx.doi.org/10.4025/actasciagron.v35i3.21251

Federer, W.T. 1956. Augmented (or hoonuiaku) designs. Hawaiian Planters Record, 55: 191-208. 
Freitas, I.L de .J..; Amaral Junior, A.T.do; Viana, A.P.; Pena, G.F.; Cabral, P.S.; Vittorazzi, C.; Silva, T.R.C. 2013. Ganho genético avaliado com índices de seleção e com REML/Blup em milho pipoca. Pesquisa Agropecuária Brasileira, 48: 1464-1471. http://dx.doi.org/10.1590/S0100204X20-13001100007

Gabriel, L.C.; Bertuzzi, C.P.; Pereira, G.P.; Coan, M.M.D.; Donel, A.A.; Tessmann, D.J.; Scapim, C.A. 2018. Avaliação da resistência de genótipos de milho pipoca ao acúmulo de fumonisinas e à podridão de Fusarium da espiga. Summa Phytopathologica, 44: 286-288. http://dx.doi.org/10.1590-/0100-5405/179360

Guimarães, A.G.; Amaral Júnior, A.T.do; Lima, V.J.; Leite, J.T.; Scapim, C.A.; Vivas, M.2018. Genetic Gains and Selection Advances of the UENF-14 Popcorn Population. Revista Caatinga, 31: 271-278. http://dx.doi.org/10.1590/1983-21252018v31n202rc

James, W.C. 1971. A manual of assessment keys for plants diseases. American Phytopathological Society, St. Paul. 90p.

Kurosawa, R.N.F.; Vivas, M.; Amaral Junior, A.T.do; Ribeiro, R.M.; Miranda, S.B.; Pena, G.F.; Leite, J.T.; Mora, F. 2017. Popcorn germplasm resistance to fungal diseases caused by Exserohilum turcicum and Bipolaris maydis. Bragantia, 77: 36-47. http://dx.doi.org/10.1590/1678-4499.2017035

Marcondes, M.M.; Faria, M.V.; Neumann, M.; Marcondes, M.M.; Silva, C.A. da; Vascoski, V.L.; Rizzardi, D.A. 2015. Desempenho agronômico e forrageiro de linhagens $\mathrm{S}_{4}$ de milho em topcrosses com híbrido simples. Semina, 36: 2395-2406. http://dx.doi.org/10.5433/1679$\underline{0359.2015 \mathrm{v} 36 \mathrm{n} 4 \mathrm{p} 2395}$

Mubeen, S.; Rafique, M.; Munis, M.F.H.; Chaudhary, H.J. 2017. Study of southern corn leaf blight (SCLB) on maize genotypes and its effect on yield. Journal of the Saudi Society of Agricultural Sciences, 16: 210-217. https://doi.org/10.1016/j.jssas.2015.06.006

Nihei, T.H.; Ferreira, J.M. 2012. Análise dialélica de linhagens de milho com ênfase na resistência a doenças foliares. Pesquisa Agropecuária Brasileira, 47: 369-377. http://dx.doi.org/10.1590/S0100-204X2012000300008

Paraginski, R.T.; Souza, N.L.; Alves, G.H.; Ziegler, V.; Oliveira, M.; Elias, M.C. 2016. Sensory and nutritional evaluation of popcorn kernels with yellow, white and red pericarps expanded in different ways. Journal of Cereal Science, 69: 383-391. https://doi.org/10.1016/j.jcs.2016.05.013

Paterniani, E. and Miranda Filho, J.B. 1978. Melhoramento de populações. In E. Paterniani, E.1978. Melhoramento e produção de milho no Brasil, 1 ed. ESALQ, Piracicaba -SP. 650p.

Peternelli, L.A.; Souza, E.F.M.; Barbosa, M.H.P.; Carvalho, M.P. 2009. Delineamentos aumentados no melhoramento de plantas em condições de restrições de recursos. Ciência Rural, 39: 24252430. http://dx.doi.org/10.1590/S0103-84782009005000209

R Core Team. 2016. R: A language and environment for statistical computing. R Foundation for Statistical Computing. Avaible from URL. https://www.r-project.org/ 
Ribeiro, R.M.; Amaral Júnior, A.T.do; Pena, G.F.; Vivas, M.; Kurosawa, R.N.F.; Gonçalves, L.S.A. 2016. History of northern corn leaf blight disease in the seventh cycle of recurrent selection of an UENF-14 popcorn population. Acta Scientiarum Agronomy, 38: 447-455. http://dx.doi.org-/10.4025/actasciagron.v38i4.30573

Sabato, E.O.; Nicésio, F.J.A.; Fernandes, F.T. 2013. Identificação e controle de doenças na cultura do milho. Embrapa Informações Tecnológicas, Brasília, DF. 198p.

Santos, A.; Amaral Junior, A.T.do; Kurosawa, R.F.N.; Gerhardt, I.F.S.; Fritsche Neto, R. 2017b. GGE Biplot projection in discriminating the efficiency of popcorn lines to use nitrogen. Ciência e Agrotecnologia, 41: 22-31. http://dx.doi.org/10.1590/1413-70542017411030816

Santos, J.S.; Amaral Junior, A.T.do; Vivas, M.; Vivas, J.M.S.; Kurosawa, R.N.F.; Silveira, S.F. 2016. Características culturais e patológicas de Bipolaris maydis em diferentes meios de cultura. Revista Brasileira de Milho e Sorgo, 15: 461-469. http://dx.doi.org/10.1590/1413$\underline{70542017411030816}$

Santos, J.S.; Amaral Junior, A.T.do; Vivas, M.; Mafra, G.S.; Pena, G.F.; Silva, F.H.L.E.; Guimaraes, A.G. 2017a. Genetic control and combining ability of agronomic attributes and northern leaf blight-related attributes in popcorn. Genetics and Molecular Research, 16. http://dx.doi.org/10.4238-/gmr16039772

Schwantes, I.A.; Amaral Júnior, A.T.do; Gerhardt, I.F.S.; Vivas, M.; Lima e Silva, F.H.de; Kamphorst, S.H. 2017. Diallel analysis of resistance to Fusarium ear rot in Brazilian popcorn genotypes. Tropical Plant Pathology, 42: 70-75. https://doi.org/10.1007/s40858-017-0136-6

Silva, T.R.C.; Amaral Júnior, A.T.do; Gonçalves, L.S.A.; Candido, L.S.; Vittorazzi, C.; Scapim, C.A. 2013. Agronomic performance of popcorn genotypes in Northern and Northwestern Rio de Janeiro State. Acta Scientiarum Agronomy, 35: 57-63. http://dx.doi.org/10.4025/actasciagron.v35i1.15694

Vencovsky, R. 1987. Herança quantitativa. In E. Paterniani. 1987. Melhoramento e produção de milho no Brasil, Fundação Cargil, 2 ed. v.2, Campinas, 409p.

Vieira, R.A.; Rocha, R. da; Scapim, C.A.; Amaral Junior, A.T.do. 2017. Recurrent selection of popcorn composites UEM-CO1 AND UEM-CO2 based on selection indices. Crop Breeding Applied Biotechnology.17: 266-272. http://dx.doi.org/10.1590/1984-70332017v17n3n40

Vittorazzi, C.; Amaral Júnior, A.T.do; Gonçalves, L.S.A.; Candido, L.S.; Silva, T.R.C. 2013. Selecting pre-cultivars of popcorn maize based on nonparametric indices. Revista Ciência Agronômica, 44:356-362. http://dx.doi.org/10.1590/S1806-66902013000200019 